\title{
A normák határozott megfogalmazásának problémája a büntetőjogban - A normavilágosság fogalma az Alkotmánybíróság döntéseiben és a bírói gyakorlatban
}

Ha azt a kérdést szeretnénk megválaszolni, hogy mi a feladata a jogelméletnek és annak a tudásnak, amelyet a jogelméleti vizsgálódások nyújtanak számunkra, a következő gondolatokkal egyetértve válaszolnék: „A jogászi tudás elméleti szempontból meghatározó vonásai közül az egyik alighanem az, hogy képessé tesz jogi tárgyú igények kompetens megítélésére. A jogászok alapvetően azzal foglalkoznak, hogy jogi igényeket formálnak, vitatnak, illetve ilyen igények felöl döntenek. A jogi gyakorlatokban való részvétel szempontjából meghatározó, hogy az ember képes legyen felismerni, mi minősülhet egyáltalán jogi igénynek, és hogy egy adott helyzetben mi minősülhet megalapozott jogi igénynek. Ez a képesség a gyakorlati okosság (vagy bölcsesség) egyik formája: egyfajta 'phronézisz' illetve 'prudentia'."1 A jogelméleti elemzések tehát sosem öncélú filozofálgatások a joggal kapcsolatos kérdésekről, hanem a jogelméletnek (legalábbis egy bizonyos részének) az a feladata, hogy hozzájáruljon a jogi gyakorlatban felmerülő problémák kompetens megválaszolásához. A gyakorlati bölcsesség elérését azáltal segíti elő, hogy a jogtudomány képviselői kidolgozzák, feltárják vagy megteremtik azokat a koherens fogalmi öszszefüggéseket a jog rendszerén belül, amelyek a (jogi) gyakorlati érvelést vezérlik és jogi döntések támpontjaiként szolgálnak.

Jelen írásban a jogelmélet e funkcióját a büntetőjogban és a büntetőjogi bírói érvelésben megjelenő probléma megvilágításán keresztül mutatom be. Hogy miért, azt magyarázhatja a következő, Montesquieu-től származó megfontolás: „Azok az ismeretek, amelyeket az ember egyes országokban szerzett és másokban szerezhet azokra a leghelyesebb szabályokra vonatkozólag, amelyeket a büntető igazságszolgáltatásban követni kell, az emberiséget a világ minden egyéb dolgánál jobban érdeklik."2 Ennek a különös érdeklődésnek több oka is lehet. A jogelmélet nézőpontjából azért tekinthető sajátosnak a büntetőjog, mert ez az a jogág, amely a legerősebb eszköz az állami hatalom kezében az emberek magatartásának irányítására, ezáltal

* Dr. Ficsor Krisztina egyetemi adjunktus, Debreceni Egyetem Állam- és Jogtudományi Kar Jogbölcseleti és Jogszociológiai Tanszék, ficsor.krisztina@law.unideb.hu. E tanulmány megírása során jelentős mértékben támaszkodtam az Acta Juridica Hungarica 2018/3. számában megjelent Certainty and Uncertainty in Criminal Law and the „Clarity of Norms” Doctrine címú írásomra.

1 Bódıg Mátyás: Jogelmélet és gyakorlati filozófia. Jogelméleti módszertani vizsgálódások. Bíbor Kiadó, Miskolc, 2004, 435.

2 Montesquieu, Charles Louis de Secondat: A törvények szelleméről. Osiris-Attraktor, Budapest, $2000,293$. 
pedig az egyéni szabadság korlátozására, a kógens kötelezettségek teremtésére. A jogelmélet (és a politikai filozófia) egyik legfontosabb érdeklődési területe az állami autoritás és jogi kötelezettségteremtés fogalmi tisztázása, megalapozása, igazolása. A tételes jogágak közül a büntetőjog ehhez alapvető kiindulópontokat kínál.

Ez a tanulmány a büntetőjogban és még inkább a büntető ítélkezésben megjelenő elméleti problémával foglalkozik: az úgynevezett normavilágosság problémájával. Bár számos büntető ítélet és alkotmánybírósági határozat foglalkozik a normavilágosság kérdésével, mindazonáltal kevés az olyan munka, amely elméleti szempontból tisztázná, hogy a fogalom mit jelent, és milyen igazolási alapokkal lehet alkalmazni a magyar gyakorlatban. A következőkben e fogalom elemzését az Alkotmánybíróság ítéleteinek elemzése segítségével és néhány bírósági határozatban megjelenő indokolás vizsgálatával végzem el.

A következőkben vizsgáljunk meg egy esetet, amelyet érint ez a probléma. 2017 áprilisában a Sándor-palota előtti demonstrációban - a Parlament által elfogadott törvénnyel szembeni tiltakozásuknak hangot adva - két résztvevő vízalapú (eltávolítható) festéket dobott a köztársasági elnök rezidenciájának falára, és azzal minimális kárt okozott. A két férfit a rendőrség letartóztatta, majd a bíróság garázdaság vádjában bűnösnek találta őket. ${ }^{3} A$ 2012. évi C. törvény, a Büntető Törvénykönyv a következő módon rendelkezik erről a büncselekményről: „339. § (1) Aki olyan kihívóan közösségellenes, erőszakos magatartást tanúsit, amely alkalmas arra, hogy másokban megbotránkozást vagy riadalmat keltsen, ha súlyosabb büncselekmény nem valósul meg, vétség miatt két évig terjedő szabadságvesztéssel büntetendő."

Az ítéletet hozó bíró szerint a vádlottak cselekménye kimerítette a garázdaság tényállásának minden fogalmi elemét. Az ügy érdekességét az adta, hogy a vádlottakat elítélő bíró 2010-ben megvédett doktori disszertációjában a garázdaság törvényi tényállásának alkotmányossági szempontú elemzését is elvégezte. Az egyik elméleti kérdés, amelyet a garázdaság törvényi fogalmával kapcsolatban feltett, az volt, hogy a jogállamiság elvének, ezen belül is a pontos törvényi meghatározottság követelményének megfelel-e az említett tényállás.

A disszertáció konklúziója szerint a garázdaság büntetőjogi tényállása a jogállamiság elvébe ütközik, mert a fogalmi elemei - alapvetően a „kihívóan közösségellenes" fogalma - túlságosan bizonytalan tartalmú és meghatározatlan. Ebből pedig az következik, hogy a bírák önkényes döntésének függvénye lehet, hogy kit, milyen feltételek alapján ítélnek el garázdaság miatt. A tényállás ezért sérti a jogbiztonság elvét, így az Alkotmánybíróságnak meg kellene semmisítenie. Állítása szerint ebben a helyzetben a bírák kötelessége, hogy az Alkotmánybíróság részére indítványt nyújtsanak be az elöttük fekvő ügyekben. ${ }^{4}$

Annak ellenére, hogy a garázdaság tényállása már 1955-től része a büntetőjog különös részének, és konzisztens bírói gyakorlat is kialakult a tekintetben, hogy milyen magatartásokat tekintenek a bírák garázdaságnak,${ }^{5}$ tartalmi értelemben mégis

A Budai Központi Kerületi Bíróság 10. B. I.650/2017/3. számú itélete.

4 HoRnYák Szabolcs: A köznyugalom elleni büncselekmények. Doktori disszertáció, 2010, 158-170 (http://ajk. pte.hu/files/file/doktori-iskola/hornyak-szabolcs/hornyak-szabolcs-vedes-ertekezes.pdf).

5 Bócz Endre: Amit hihetetlennek gondoltam valaha... Élet és Irodalom, 2017/61, 5. 
erősen vitatott a tényállás jelentése. ${ }^{6} \mathrm{~A}$ „kirívóan közösségellenes” magatartás fogalma nem tisztázható anélkül, hogy a bíró erkölcsi mérlegelésbe ne bonyolódna a közösségi együttélés alapvető erkölcsi feltételeiröl és elveiröl.

Ebben a tanulmányban nem az a célom, hogy a garázdaság tényállását elemezzem és tisztázzam. Ennek az esetnek a megemlítése azért releváns, mert rámutat, hogy a 21 . században továbbra is probléma, hogy miképpen lehetséges a jogrendszer szabályait és a bírói döntéseket az állampolgárok számára érthetően és világosan megfogalmazni.

A következő alfejezetekben arra törekszem, hogy a jogbiztonság kérdését a bírói gyakorlat és az Alkotmánybíróság gyakorlata szemszögéből világítsam meg. Az Alkotmánybíróság hatáskörébe tartozik, hogy megsemmisítheti azon jogszabályokat, amelyek megfogalmazása nem elégíti ki az ún. normavilágosság követelményeit. Mivel a jogi normák értelmezése a bírák feladata, a bírói gyakorlat nézőpontjából is érdemes megvizsgálni, hogy ott hogyan jelenik meg a jogbiztonság követelménye. Álláspontom szerint a magyar bírói gyakorlatban a büntetőjogi normák értelmezésének alapja a nyelvi értelmezés, ${ }^{7}$ ami azt jelenti, hogy ezen a területen a jelentés feltárásának fő módszere a szavak hétköznapi, szó szerinti jelentésének vizsgálata, ami kizárja a büntetőjogi normák mögött meghúzódó, azokat igazoló erkölcsi értékek, elvek tartalmának mérlegelését. A büntetőjogban azért különösen fontos a mérlegelést nem engedő értelmezés alkalmazása, mert a jog e területén valósul meg leginkább a szabadság kényszer útján történő korlátozása. Emiatt garanciális elemeket kell beépíteni a büntetőjogba (például a normák pontos meghatározásának elve, az analógia tilalma, nullum crimen sine lege elve stb.), amelyek biztosítják, hogy az egyének szabadsága nem sérül indokolatlanul. Az a célom ebben a dolgozatban, hogy megvilágítsam ennek a bírói attitűdnek a hátrányos elvi következményeit. Amellett érvelek majd, hogy a büntetőjogi normák bizonytalanságaival történő bírói szembenézés helyes stratégiái túlmutatnak a puszta nyelvi értelmezésen. A büntetőjog bírói értelmezésének nagyobb hangsúlyt kellene fektetnie a normák mögött meghúzódó erkölcsi értékek tartalmának vizsgálatára (természetesen a legalitás elveinek tiszteletben tartásával).

6 Mutatja ezt a Kúria legutóbbi döntése is annak az operatőrnek az ügyében, aki 2015-ben a bevándorlással kapcsolatos tudósítás közben egyet megkísérelt, két menekültet pedig lábon rúgott. A Kúria véleménye szerint kihívóan közösségellenesség hiányában az eset nem tekinthető garázdaság vétségének. Lásd a Kúria Bfv.III.796/2018. számú döntését, illetve http://www.lb.hu/hu/sajto/megvadolt-operator-cselekmenye-nemvalositotta-meg-garazdasag-vetseget (2018. 11. 05.). Meglátásom szerint viszont más emberek rugdosása önmagában kihívóan közösségellenes magatartásnak tekinthetö.

7 Tekintettel arra, hogy a szerző egyetért Blutman László azon véleményével, hogy a „nyelvtani értelmezés" fogalma nem ragadja meg teljes mértékben ennek az értelmezési módszernek a valódi funkcióját, a szerző ebben a tanulmányban a „nyelvi értelmezés” kifejezést használja. Blutman álláspontja szerint a „nyelvtani” kifejezés pusztán arra az értelmezési tevékenységre utal, amely során feltárjuk „a nyelv egységeinek egymás közötti formális szerveződési szabályait”, azaz a nyelvtani szabályokat. Ez az értelmezési mód azonban többről szól, mint pusztán a nyelvtani összefüggések feltárása, ez magában foglalja a szöveggel kapcsolatos pragmatikai és a szemantikai vizsgálódásokat is. Lásd BLUTMAN László: Egy empirikus jogértelmezéstan szükségessége. Jogtudományi Közlöny, 2008/1, 4. 


\section{A jogállamiság elvi követelményei a büntetöjogban a normavilágosságra vonatkozóan}

A büntetőjogban a jogszabályok pontos, világos megfogalmazásának követelménye elengedhetetlen, hiszen - mint a jogszabályoknak általában - az a funkciója, hogy emberi magatartásokat kiszámítható, előre látható módon vezéreljenek, illetve arra hivatottak, hogy a bírói döntések számára koherens és konzisztens igazolási alapot teremtsenek.

Modern alkotmányos demokráciákban a büntetőjogot a szabályok olyan rendszerére kell felépíteni, hogy képes legyen a magatartásokat hatékonyan irányítani, miközben elvi garanciák biztosítják, hogy a hatóságok e normákat az emberi jogok és az egyének autonómiájának tiszteletben tartásával alkalmazzák. Ahogy Montesquieu megállapítja: „A politikai szabadság a biztonságban áll, vagy legalábbis abban a véleményben, amelyet az ember saját biztonsága felöl alkot. Ezt a szabadságot semmi sem veszélyezteti erősebben, mint a köz-, vagy magánvádak. Az állampolgár szabadsága elsősorban a büntetőtörvények jóságától függ."8

Először is arra törekszem a tanulmány e részében, hogy felvázoljam a jogállamiság elveit a büntetőjogban, amelyek a jogbiztonság, kiszámíthatóság előmozdítására hivatottak. Az elvek e vázlatának kialakításában az Andrew Ashworth által kidolgozott rendszerre támaszkodom, majd a magyar büntetőjogi felfogásban megmutatkozó, az angolszász büntetőjogi elvektől eltérő, speciális elemeket világítom meg.

Andrew Ashworth az egyike azon büntetőjoggal foglalkozó jogfilozófusoknak, aki az (angolszász) büntetőjogot megalapozó erkölcsi elvek rendszerét és az elvek tartalmát a legalaposabban kidolgozta. Ezért is támaszkodom elsősorban az ő elméletére, amikor vázolom a témám szempontjából releváns elveket. Ashworth szerint az angolszász büntetőjogban két alapvető elv feszültsége határozza meg a büntetőjog igazolási hátteréröl és az erkölcsi alapjairól szóló tudományos vitákat. Az elvek egyik csoportjának funkciója az, hogy korlátozzák a büntetőjogot alkotó és alkalmazó intézmények hatalmát. $E$ korlátozó elvek megkövetelik, hogy a törvényhozók és a bírák tartsák tiszteletben hatalmuk korlátait, amikor megalkotják, illetve alkalmazzák a büntetőjogi normákat. A korlátokat megfogalmazó elvek közé sorolhatjuk a visszaható hatályú normaalkotás és alkalmazás „tilalmát”, a jogszabályok pontos megfogalmazásának követelményét és azt az elvárást, hogy bizonytalanság esetén a jogszabályt a vádlott javának megfelelően kell értelmezni. ${ }^{9}$

A visszaható hatályú normákkal kapcsolatos követelmény, hogy a bírák a büntetőjogban - bizonyos kivételekkel - kizárólag az elkövetés idején hatályban lévő jogszabályt alkalmazhatják. A büntetőjogban ítéletet hozni az egyénekkel szemben csak olyan normák alapján lehetséges, amelyek korábban az adott cselekményt bủncselekménnyé nyilvánították, tehát a bírói ítélet akkor legitim, ha a jogeset tényei valamely előzetesen rögzített büntetőjogi szabály tényállási elemeit teljes mértékben kimerítik. Ez az elvi követelmény tükrözi a jogrendszer elköteleződését amellett, hogy az állampolgárok racionális, autonóm lények, akik számára alapvető fontos-

8 Montesquieu: i. m., 293.

9 Horder, Jeremy: Ashworth's Principles of Criminal Law. Oxford University Press, Oxford, 2016, 66. 
ságú, hogy életük tervezése során elöre láthassák, hogy a jog milyen magatartást kíván meg tölük. ${ }^{10}$

A jogállamiság másik fontos büntetőjogi garanciája a normák pontos megfogalmazásának követelménye (principle of maximum certainty) azt várja el a jogalkotótól, hogy a jogszabályok szövegét oly módon fogalmazza meg, hogy a laikus állampolgárok számára is világos, érthető legyen, milyen magatartásokat kívánnak meg tölük. A jogbiztonság érvényesülése szempontjából fontos, hogy a büntető jogszabályok pontos, egyértelmű megszövegezés útján kommunikálják, hogy a címzettek milyen jogokkal és kötelezettségekkel rendelkeznek. ${ }^{11} \mathrm{~A}$ Velencei Bizottság által kiadott, a jogállamiság európai követelményeivel kapcsolatos jelentésében szintén szerepel az a kitétel, hogy „a jogbiztonság követelménye alapján a jogi szabályokat világosan és pontosan kell megfogalmazni, és annak biztosítására kell törekedni, hogy a jogi szituációk és viszonyok elöreláthatóak legyenek". ${ }^{12}$

Ezentúl az állam büntető hatalmának korlátozása szempontjából meghatározó jelentősége van annak az elvnek is, amely a bírói döntésre vonatkozóan azt a követelményt fogalmazza meg, hogy bizonytalanság, a norma jelentését érintő kétség esetén a normának azt az értelmezését kell választani, amelyik a vádlott javát szolgálja. ${ }^{13}$

A fent említett elvek két fontos érték realizálására hivatottak a (büntetö)jogban. Az egyik oldalon megjelenik bennük az egyén mint racionális, a jó életröl alkotott felfogását önmaga számára kialakítani képes személy tisztelete. A másik oldalon ebből következően a politikai intézmények hatalmának erkölcsi korlátait jelenítik meg, amelyek kizárják a lehetöségét, hogy önkényes döntések szülessenek. ${ }^{14}$

A hatalom korlátait kijelölő elvek mellett Ashworth szerint az angolszász jogba azonban az úgynevezett „autoritásra épülő” elv (authoritarian principle) is beépült. Ez az elv a büntetőjognak egy sokkal rugalmasabb felfogását képviseli, amely alapján bizonyos feltételek mellett olyan magatartás miatt is elítélhetnek a bíróságok egy személyt, amely teljes mértékben nem meríti ki valamely előzetesen rögzített jogszabály tényállási elemeit, de a bíróság úgy ítéli meg, hogy a magatartás egyébként a büntetőjog hatókörébe tartozna. ${ }^{15} \mathrm{Ha}$ az ítélkezést ez az elv vezérli, a bíróságnak diszkrecionális joga van arra vonatkozóan, hogy abban az esetben, ha a konkrét jogesetre nem alkalmazható teljes körüen egy jogszabály, eldöntse, hogy az adott magatartást észszerủ indokok alapján büntetni rendeli-e. Teheti ezt úgy, hogy új tényállást konstruál vagy kiterjeszti a meglévő jogszabály értelmét az előtte lévő esetre is. Ennek az elvnek a büntetőjogba építésével reflektálhatunk a folyamatosan

10 Horder (2016): i. m., 82-83. Ezt a követelményt az Alaptörvény is megfogalmazza: XXVIII. cikk (4) Senki nem nyilvánítható bűnösnek, és nem sújtható büntetéssel olyan cselekmény miatt, amely az elkövetés idején a magyar jog vagy - nemzetközi szerződés, illetve az Európai Unió jogi aktusa által meghatározott körben - más állam joga szerint nem volt bủncselekmény.

11 HoRder (2016): i. m., 85.

12 A Velencei Bizottság jelentése a joguralomról, 2011. (Elfogadva a Velencei Bizottság 86. plenáris ülésén 2011. március 25-26.)

13 HORDER (2016): i. m., 87.

14 HORDER (2016): i. m., 86-87.

15 Horder (2016): i. m., 89. 
változó világra, amelyben új típusú bủncselekmények mindig megjelennek. Ez az elv testesíti meg a büntetőjogban az ún. „vékony jég” tézisét, amely kimondja, hogy azok, akik tisztában vannak vele, hogy magatartásuk a jogtalanság határait súrolja, számítaniuk kell arra a lehetőségre, hogy elítélhetik őket büncselekmény elkövetése miatt. ${ }^{16}$

A magyar büntetőjog a jogállamiság hasonló elveire épül fel, de természetesen különbözik is az angolszász jogrendszertöl. A legalitás elvét föként az ún. nullum crimen sine lege elve tükrözi a magyar jogban, amely Nagy Ferenc elemzése alapján négy „alelvre” bontható szét. Ezek a visszaható hatályú jogalkotás tilalma, az írott jog elsődlegessége, az analógia tilalma, valamint a jogszabályok pontos meghatározásának követelménye. ${ }^{17} \mathrm{Az}$ első három összetevő egyértelmüen a vádlott hátrányára történő jogalkotás és a jogalkalmazás tilalmát fejezi ki.

A magyar jogban a büntetőjogi felelősség megállapítása és büntetés kiszabása kizárólag előzetesen rögzített jogszabály alapján történhet. A bíróságok nem változtathatják meg a már elöre rögzített tényállások elemeit, nem alkothatnak új tényállást. Ebben a kontextusban a jogbiztonság azt jelenti, hogy az állampolgárok kizárólag akkor képesek meghatározni, hogy milyen jogokkal és kötelezettségekkel rendelkeznek, ha előzetesen rögzített jogi normákból tájékozódhatnak.

Az analógia tilalma azt jelenti, hogy a bírák értelmezéssel nem terjeszthetik ki egy már meglévő norma tartalmát valamely új, még nem szabályozott esetre. Ebből az következik, hogy a bírói értelmezés kötve van a jogszabály pontos szövegéhez, és nem támaszkodhat a jogszabály szövegén túli indokokra. A nyelvi értelmezést alkalmazva a bírónak az a feladata, hogy a jogszabályok szemantikai tartalmát tárja fel, és lehetőleg ne támaszkodjon egyéb értelmezési módszerekre, például a teleologikus értelmezésre, amely a jogszabály mögött meghúzódó igazolási elveket, erkölcsi értékeket, célokat teszi az értelmezés tárgyává. A büntetőjogban a jogot igazoló erkölcsi értékek nem lehetnek alapjai a jogi érvelésnek, mert azok erősen vitatottak, több racionális értelmezésnek is teret engednek, kiszámíthatatlanná tennék a bírói gyakorlatot. „Szembetünő tény, hogy a jogi érvelés gyakorlata egyetlen modern jogrendszerben sem aknázza ki a jogi érvelés összes elméletileg plauzibilis lehetöségét. Mindenhol léteznek olyan jogi doktrínák, sőt jogi szabályok, amelyek kizárnak bizonyos érvelési technikákat. Ennek legnyilvánvalóbb példája a büntetőjogi érvelés, ahol mind a büntetőjogi felelősség megállapításakor, mind pedig a büntetések kiszabásakor szigorú törvényhez kötöttség érvényesül."18

Ebből következően az ún. autoritásra épülő elv nem része a magyar jognak. Ennek az elvnek azonban az lenne a funkciója, hogy megvilágítsa a bírói gyakorlatban gyakran előforduló jelenséget: azt, hogy a büntetőjog normáinak szövege nem mindig kínál egyetlen helyes választ a konkrét esetekben. Ezekben az esetekben a bíró választásra szorul, és a választását meg kell indokolnia, az indokolásnak pedig ilyenkor elkerülhetetlenül szövegen túli indokokra, például a jogszabály

16 „Azok, akik vékony jégen korcsolyáznak, aligha számíthatnak arra, hogy találnak egy pontot, amely minden kétséget kizáróan kijelöli, hol szakad be a jég." Lord Morris: Knuller v. DPP. Idézi Horder (2016): i. m., 89.

17 NAGY Ferenc: A nullum crimen/nulla poena sine lege alapelvröl. Magyar Jog, 1995/5, 257-270.

18 Bódig Mátyás: Egy hiányjelenség a jogban: a joghézag. Café Bábel, 2006/53, 41. 
mögöttes igazoló elveire is támaszkodnia kell. Ezzel szemben arra szeretnék rámutatni, hogy a magyar bírói gyakorlatban a nyelvi értelmezés (sok esetben az értelmező kéziszótárak felhasználásával) uralja a büntetőjogi normák értelmezését a fent felsorolt jogállami követelmények miatt. Azonban az is igaz, hogy ez az értelmezési stratégia nem mindig alkalmas arra, hogy megalapozza a helyes jogi döntést.

Montesquieu értelmezésében a polgárok szabadsága a büntetőjogi szabályok „jóságán” múlik. Összefoglalva a fent megfogalmazott elveket, a büntetőjogi normák „jósága” a következőkben nyilvánulhat meg:

Egyrészt képesnek kell lenniük arra, hogy hatékonyan irányítsák az állampolgárok magatartását (azaz pontosan meghatározzák, hogy milyen magatartást várnak el és tiltanak meg), illetve képessé teszik őket arra, hogy kétséget kizáróan meg tudják érteni a jogszabályok jelentését. Másrészt tiszteletben tartják az állampolgárok emberi jogait, mert tükrözik annak elismerését, hogy önálló, autonóm és szabad személyek, akik képesek meghatározni a jó életről alkotott felfogásukat, vagyis azt, hogy milyen értékek és célok vezéreljék az életüket. Alkotmányos demokráciákban a büntetőjogi normákat alkotó és alkalmazó politikai intézmények tiszteletben tartják a hatalmukat korlátozó emberi jogokat és politikai értékeket.

\section{A büntetőjogi normák pontos meghatározottságának követelménye és az Alkotmánybíróság gyakorlata}

A jogbiztonság néhány büntetőjogi elvének vázlata után a tanulmány fókuszpontját arra a kérdésre helyezem, hogy az Alkotmánybíróság (a továbbiakban: $A B$ ) határozataiban milyen értelmezését nyújtja az „érthetőség” elvének, tehát annak, hogy miképpen jelenik meg a normák pontos meghatározásának követelménye az $A B$ gyakorlatában, kirajzolódik-e ennek az elvnek valamilyen koherens elmélete. A jogszabályok pontos meghatározottságának követelményét a "normavilágosság” elve fogalmazza meg az $A B$ határozataiban, amely alapján az $A B$ megsemmisítheti az adott jogszabályt, ha az nem felel meg az elvben foglaltaknak. A jogi normák alkotmányellenességét ugyanis önmagában megalapozza az a tény, hogy azok érthetetlen, homályos megfogalmazásúak, többféle egymásnak ellentmondó értelmezésnek adnak lehetöséget.

Ebben a kontextusban a legfontosabb elméleti kérdés, hogy a normavilágosság követelménye hogyan jelenik meg az $A B$ gyakorlatában és a büntetőjogi normák rendes bírósági értelmezésére vonatkozóan milyen elvárásokat fogalmaz meg ez az elv. Tehát a megválaszolásra szoruló kérdés az, hogy a normavilágosság, a jogszabályok határozottságának problémája miképpen ragadható meg elméleti szempontból? Tekintetbe véve ugyanis azt a tényt, hogy a jogszabályok szövegét lehetetlen kialakítani oly módon, hogy azok teljesen pontosak legyenek és lefedjenek minden lehetséges jövőben előforduló esetet, kardinális kérdés, hogy a határozottság problémáját miképpen ragadhatjuk meg, illetve hogyan valósítható meg a jogban. Mit jelent, hogy egy norma világos? Lehetséges-e éles határvonalat húzni azon normák között, amelyek tartalma bizonytalan, de még alkotmányosnak számítanak, és azok között, amelyek határozatlansága már olyan szintű, hogy sérti a jogbiztonság elvét, 
ezért alkotmányellenesek? Léteznek-e pontos kritériumok, amelyek alapján megállapítható egy norma határozatlansága? Mi a szerepe ebben a rendes bíróságoknak, amelyek a jogszabályokat értelmezik? Mivel a jogszabályok bírói értelmezése csaknem minden egyes jogeset megítélése kapcsán elkerülhetetlen, a bírák felhatalmazása meddig terjedhet egy norma pontos értelmének meghatározásakor?

\subsection{A büntetőjogi normák címzettjei}

A fenti kérdések megválaszolásának előfeltétele, hogy egy alapvető problémára adjunk választ. Mivel a normavilágosság követelménye azt fogalmazza meg, hogy a jogszabályoknak érthetőeknek és világosaknak kell lenniük, azt a kérdést szükséges feltenni, hogy kik a büntető jogszabályok címzettjei. ${ }^{19}$ Kik azok, akik számára a jogszabályoknak érthetően kell közvetíteniük a jelentésüket? A címzettek szempontjait figyelembe véve a normavilágosság problémája két dimenzióban értelmezhető.

A címzettek egyik csoportját maguk az állampolgárok jelentik. Ha a normák határozottságának problémája a tisztázandó kérdés, akkor azt kell megvilágítani, hogy az állampolgárok szemszögéböl tekintve mit jelent a világosság, a határozottság, a pontosság. Innen nézve a vizsgálódás tárgya az állampolgárok perspektívájának elemzése és tisztázása lehet a feladat, hiszen ők azok, akiknek az életét a jogszabályok tartalma közvetlenül érinti, tölük várnak el a normák engedelmességet.

A címzettek másik csoportját a bírák képezik, mert ők azok, akik megállapítják, hogy az állampolgároknak mit kell tenni a jogszabályok alapján, ők értelmezik és állapítják meg kötelező erővel a jogszabályok jelentését. Ebben a kontextusban pedig a határozottság problémája úgy jelenik meg, hogy a büntető jogszabályoknak azt kell biztosítaniuk, hogy a bírák önkényes döntését kizárják.

\subsection{A normavilágosság problémája az Alkotmánybíróság gyakorlatában}

Az Alkotmánybíróság inkább negatív módon határozza meg a normavilágosság követelményét ítéleteiben: azt a kérdést válaszolja meg, hogy a normáknak milyen típusú megfogalmazása tekinthető az alkotmányosságot érintően határozatlannak. A határozatlanságnak az egyik típusa az, amikor a jogszabály túl tágan fogalmaz, tehát a jogszabályba foglalt fogalmak túlságosan absztraktak és általánosak. A bírói gyakorlatban az ilyen jogszabályok lehetőséget adnak a bíráknak arra, hogy a tartalmukat önkényesen állapítsák meg. Ez azt jelenti, hogy a túlságosan absztrakt jogi fogalmak nagyobb mozgásteret biztosítanak a bírák számára, amely azt a veszélyt is magában rejti, hogy a szubjektív elképzeléseik alapozzák meg a döntéseiket. Ebben az esetben inkoherens, kiszámíthatatlan bírói gyakorlathoz jutunk, amelyen

19 Gellér Balázs József: Legality on Trial. A Theoretical Analysis of the Legality of Substantive Criminal Norms. Eötvös University Press, Budapest, 2012, 65-94. 
belül többféle egymásnak ellentmondó döntés is születhet ugyanazon norma értelmezése alapján. ${ }^{20}$

A határozatlan jogszabály másik típusa, amelyet a testület megemlít határozataiban, annak lehetősége, hogy a jogalkotó „túl szűken” határozza meg a norma fogalmának tartalmát. Ez akkor nyilvánulhat meg, ha a jogalkotó kimerítő felsorolásra törekszik a norma megfogalmazásakor, tehát megpróbálja az adott cselekmény összes lehetséges előfordulási esetét a norma szövegébe illeszteni, kazuisztikus normát alkot. Az ilyen típusú normaalkotás veszélye abban mutatkozik meg, hogy rugalmatlanná teheti a büntetőjogot a társadalmi, gazdasági változásokkal szemben: arra „kényszerítheti” a bírákat, hogy „megszorítóan” értelmezzék a jogszabályt, melynek következményeként olyan magatartást sem vonhatnak a jogszabály hatálya alá, amelyet - tekintetbe véve a jogszabály mögött meghúzódó igazolási elveket és a büntetőjog alapvető céljait - igazoltan büntetni kellene. Ez azt jelentené, hogy a bírónak olyan elkövetőt is fel kellene mentenie, akinek cselekményét az említett igazolási elvek alapján büncselekménynek tekinthetnénk, azonban a jogszabály szövege nem tartalmazza explicit módon az adott magatartást. Mivel az analógia tilalma és a „kiterjesztő” értelmezés tilalma uralja a büntetőjog bírói értelmezését, nem maradna más lehetőség, kizárólag a fent említett elkövető felmentése. ${ }^{21}$

Bizonyos esetekben az AB elutasítja azokat az indítványokat, amelyek a jogszabály túl absztrakt szövegezése miatt annak alkotmányellenessége és megsemmisítése mellett érvelnek. $A z A B$ részéről az elutasítás indoka általában az, hogy a büntetőjognak képesnek kell lennie arra, hogy a változó társadalmi, gazdasági körülményekhez igazodjon, ehhez pedig az szükséges, hogy a jogalkotó absztrakt, rugalmas fogalmakat építsen be a jogba. Az AB egyik legfontosabb érve annak alátámasztására, hogy a büntetőjogi normákat absztrakt, általános módon kell megfogalmazni, hogy bizonyos cselekményeket megszámlálhatatlanul sokféle módon lehet elkövetni. (Gondoljunk például az emberölés vagy a lopás tényállására.) Ha ezekben az esetekben a jogalkotó arra törekedne, hogy minden lehetséges elöfordulási esetet taxatíve rögzítsen a tényállásban, szintén szembekerülne a jogállamiság elvével. A bíróságoknak nem lenne lehetősége olyan cselekmények miatt elítélni a vádlottakat, amelyek - tekintetbe véve a büntetőjog funkcióját és igazolási alapjait - bủncselekménynek számítanának, de nem tartalmazná őket explicit módon a jogszabály szövege. „A »tartalmilag elvontabb« tényállások esetében az elkövetési magatartások az életben olyan széles körben és olyan változatos módon jelentkezhetnek, hogy azok előzetes, kimerítő felsorolása nem lehetséges. Ebben az esetben a joghézagot éppen az jelentené, ha a jogalkotó »kazuisztikusan«, illetve taxatíve vagy példálózóan sorolná fel a visszaélések egyéb változatait. Ezzel ugyanis alkalmat teremtene az analógia - büntetöjogban tilos - alkalmazására, vagy lefedetlenül hagyná a bünözésben megjelenő újabb módszereket és formákat, s így megakadályozná, hogy a büntetö törvény betöltse rendeltetését. Ezért az ilyen ese-

20 Lásd a következő alkotmánybírósági határozatokat: $28 / 2012$. (XI. 14.) $A B$ határozat; 31/2015. (XI. 18.) $A B$ határozat; 4/2013. (II. 21.) $A B$ határozat; 18/2000. (VI. 6.) $A B$ határozat; 3284/2017. (XI. 14.) $A B$ határozat.

21 Azonban nehéz olyan $A B$ határozatot találni, amelyben a testület kazuisztikus megfogalmazása miatt semmisített volna meg büntetőjogi tényállást. 
tekben a tényállás »absztrakt» jellege olyan jogtechnikai megoldást jelent, amely a jogállamiság alkotmányos alapelvét nem sérti."22

Azokban az esetekben, amelyekben a büntetőjogi tényállásban nem lehetséges a tiltott magatartás minden előfordulási esetét taxatívan megfogalmazni, a bírónak (nem korlátlan) diszkrecionális joga lesz eldönteni, hogy mely magatartások tartoznak a büntető szabályba foglalt fogalom jelentéskörébe. Tehát az absztrakt fogalmak tartalmának tisztázása a bírákra háruló feladat, amelynek során értelmezés segítségével határozzák meg a fogalom tartalmát. Az ilyen absztrakt tényállások tartalma a bírói gyakorlat kialakítása útján lesz világos és pontos. ${ }^{23}$

Léteznek azonban olyan tényállások is, amelyek esetében a túl tág és absztrakt megfogalmazást az AB alkotmányellenesnek ítélte, mert azok túl széles diszkrecionális jogkört biztosítottak a bírák számára, hogy a jogszabályba foglalt fogalmak tartalmát meghatározzák. ${ }^{24}$

A probléma azonban, amely az AB döntéseiböl kirajzolódik, hogy nehéz felfedezni az érvelései mögött egy koherens, konzisztens elméleti bázist, amely alapján megállapítható lenne, hogy mely esetekben szükséges a büntetőjogi szabályokat rugalmas, általános fogalmak segítségével megalkotni (amikor is a bírák feladata lenne a szabályok tartalmának tisztázása értelmezés útján), és melyek azok az esetek, amikor a jogalkotónak pontos, világos, egyértelmű szöveget kell kialakítania (amikor a bíráknak a jogszabály szövegének pontos és világos jelentésére kellene támaszkodnia anélkül, hogy „kreatív” értelmezési módszerekhez folyamodnának - tehát a bírói gyakorlat nem „alakíthatná” a jogszabály rögzített tartalmát). Röviden: az AB határozataiban nem rajzolódik ki egy koherens elmélet a jogszabályok határozottságának (a jogbiztonság) követelményéröl.

22 Lásd a 673/B/2004. AB határozatot.

${ }^{23}$ A 673/B/2004. számú határozatában is hasonlóan érvelt a testület, amikor megállapította, hogy az 1978. évi IV. törvényben (régi Btk.) a pénzmosásra vonatkozó bejelentési kötelezettség elmulasztásának tényállása nem alkotmányellenes. A 769/B/2006. számú határozatában szintén ehhez hasonlóan támasztotta alá azt a döntését, hogy az „alárendelt megsértése” címü tényállás nem alkotmányellenes. Ezekben az esetekben az $A B$ azt a tézist támogatta, hogy az említett magatartások sokféle módon elkövethetők, ezért nem is lehet kimerítően felsorolni a tényállásokban az elkövetési magatartásokat. A jogalkotó ezért - amikor általános és absztrakt módon fogalmazta meg e jogszabályokat - nem sértette meg a jogállamiság elvét.

24 A 38/2018. (XI. 14.) számú határozatában a testület a közterületen való életvitelszerú tartózkodás szabálysértési tényállását semmisítette meg a fent meghatározott érveléssel. A Szabálysértésekről szóló törvény (2012. évi II. törvény) szövege az AB döntésének idején így szólt: „186. § (1) Aki a közterület belterületét rendeltetésétől eltérő módon, életvitelszerü lakhatás céljára használja, illetve életvitelszerü lakhatáshoz használt ingóságokat közterületen tárol, szabálysértést követ el. (2) Az (1) bekezdésben meghatározott szabálysértés nem állapitható meg, ha a feladat ellátására kötelezett önkormányzat a hajléktalan-ellátás feltételeit nem biztositja. (3) Az (1) bekezdésben meghatározott szabálysértés miatt a közterület-felügyeló is szabhat ki helyszíni bírságot." A testület véleménye szerint csaknem az összes jogszabályba foglalt fogalom homályos, nehezen értelmezhető, mert a jogszabály nem teszi egyértelművé, hogy pontosan milyen magatartások számítanak szabálysértésnek, azt sem, hogy milyen esetekben állapíthat meg a bíró büntethetöséget kizáró vagy megszüntető okokat. Összességében a testület véleménye szerint a jogszabályba foglalt fogalmak oly mértékben általánosak, hogy azok tartalmának tisztázását a bírói gyakorlat sem képes koherens és konzisztens módon elvégezni. 


\subsection{A bíró nézőpontjának hangsúlyozása}

Úgy tünik, hogy az $A B$, amikor a normavilágosság követelményeit megfogalmazza, elsősorban nem az állampolgárok perspektíváját veszi tekintetbe, hanem a bírákét. ${ }^{25}$ Ebben a kérdésben az AB-val egyetértve azt állítom, hogy a bírák nézőpontja valóban elsődleges az állampolgárokéval szemben.

Miért a bíró nézőpontja a hangsúlyos akkor, amikor a jogszabályok határozottságának kérdését vizsgáljuk? Egyrészt azért, mert a jogszabályok jelentését „véglegesen" a bírák határozzák meg az értelmezés segítségével, az állampolgároknak pedig engedelmeskedniük kell a bírói döntésnek abban az esetben is, ha ők a jogszabály másfajta értelmezését fogadnák el. Másrészt nem lehetséges a normavilágosságnak olyan objektív kritériumait meghatározni, amelyek alapján a jogalkotó olyan jogszabályokat alkothatna meg, amelyek szövegét a politikai közösség minden egyes tagja képes lenne azonos módon megérteni. A jogelméletben létezik olyan felfogás, hogy egy jogszabály akkor egyértelmü, ha azt egy átlagos intelligenciájú, józan gondolkodású laikus polgár is meg tudja érteni. ${ }^{26}$ Mindazonáltal az állampolgárok nem rendelkeznek azonos intelligenciával és bölcsességgel a jogszabályok tartalmának értelmezését illetően sem, a büncselekmények potenciális elkövetői pedig általában nem foglalatoskodnak a büntetőtörvények olvasgatásával, mielőtt elkövetik a büncselekményt.

Az is megtörténhet, hogy magas intelligenciájú laikus állampolgár sem képes megérteni a büntetőjogi dogmatikát, a bonyolult fogalmi összefüggéseket, amelyek a büntetőjog és szabályai mögött meghúzódnak ${ }^{27}$ Valószínűleg helytálló megállapítás, ha kijelentjük, hogy a laikus állampolgárok nem hajlanak arra, hogy a jogszabályokat olvasgassák és értelmezzék. Ha pedig büntető tárgyaláson kell részt venniük például vádlottként, a legfontosabb kérdés számukra, hogy a bíró miképpen fog dönteni. ${ }^{28}$ Ebben a kérdésben pedig inkább jogász szakemberek, ügyvédek vé-

25 Lásd például a 3258/2015. (XII. 22.) AB határozatot.

26 Gellér: i. m., 80.

27 Ennek érdekes példája az a kúriai döntés, amelyben a terheltek ellen mủemlék megrongálása (új Btk. 357. §) miatt emelt vádat az ügyész. A vádlottak egy müemléknek minősülö kastély tulajdonosai voltak, a vád szerint pedig azáltal, hogy nem tettek eleget a közigazgatási szabályok által meghatározott müemlékvédelmi kötelezettségeiknek - a kastélyon egyáltalán nem végeztek állagmegőrzést célzó munkálatokat, amely ennek következtében károsodott -, elkövették a büncselekményt. A tárgyalás idején az egyik vádlott joghallgató volt, és azzal érvelt, hogy nem követték el a büncselekményt, mert a tankönyve alapján szerinte a múemlék megrongálása kizárólag aktív és szándékos magatartással követhető el. A vádlottak pedig pusztán annyit tettek, hogy a törvényben meghatározott javítási kötelezettségeiket elmulasztották, ami passzív magatartás és semmi esetre sem szándékos. A Kúria ennek ellenére elítélte a vádlottakat, döntését pedig a büntetőjogi dogmatika segítségével alapozta meg, amely során a nyitott törvényi tényállások lényegét tisztázta az indokolásában. Ebböl világossá válik, hogy a jog szövegében ki nem fejtett mély dogmatikai összefüggéseket egy magas intelligenciával bíró laikus állampolgár sem képes feltárni, az az állampolgárok legnagyobb része számára „rejtve marad”, és csak bírói értelmezéssel tárható fel. (Lásd a Kúria Bfv. II.13./2009/5. számú itéletét.) [Ebböl nem következik, hogy a bíróság döntése helyes volt. Ezzel az üggyel kapcsolatban lásd a 3077/2012. (VII. 26.) AB határozatot, különös tekintettel Pokol Béla különvéleményére.]

28 Ahogy Oliver Wendell Holmes fogalmaz: „Ám ha magunkévá tesszük barátunk, a rossz ember szemléletét, láthatjuk, hogy emezt jottányit sem izgatják az axiómák és dedukciók, ellenben tudni akarja, ténylegesen milyen döntés várható Massachusetts és Anglia bíróságaitól. Sok szempontból egy rugóra jár az agyunk. 
leményére támaszkodnak, nem a jogszabályok jelentésével kapcsolatos saját vélekedéseikre.

A jogalkotó tehát nem lehet képes arra, hogy a politikai közösség összes tagja számára tökéletesen érthető jogszabályokat hozzon létre: a határozatlanság problémája örökös jelenség a jogban. Ez pedig alapvetően annak köszönhető, hogy a jogszabályok természetes nyelven íródtak, és a természetes nyelv karaktere, valamint az őt jellemző problémák a jogi nyelvben megjelenő problémákat is meghatározzák. Herbert Hart érveinek jelentősége ebben a kontextusban is megmutatkozik: „A szabályok által megkívánt magatartásformát illetően egyes konkrét esetekben még akkor is bizonytalanságok támadhatnak, ha szavakban megfogalmazott általános szabályokat használunk. Az egyes tényállások nem várnak ránk egymástól elhatárolva és az alkalmazandó általános szabály egyedi eseteiként felcímkézve, és a szabály maga sem úgy lép elénk, hogy megjelöli saját alkalmazási eseteit. Az általános kifejezésekben nyújtható útmutatásnak nem csupán a szabályok esetén, de a tapasztalati megismerés minden területén határa van, s ez a nyelv természetében rejlik." 29

A határozatlanság problémája a jogban azonban nem pusztán nyelvi természetü, hanem a jog argumentatív karakterének is meghatározó jelentősége van a kialakulásában. Mivel a jogszabályok normatív állítások azzal kapcsolatban, hogy mit kell tenni, minden egyes, a tartalmukkal kapcsolatos jogi álítás vitatható, cáfolható. Mivel a jogi állítások nem rendelkeznek a természettudományokban megfogalmazott állítások és következtetések objektivitásával, a jogi döntésekről sem állíthatók, hogy azok az egyetlen helyes választ testesítik meg minden egyes esetben. Előfordulhat, hogy ugyanazon jogszabálynak hasonló esetben két vagy több racionális értelmezése is kialakítható, ebböl következően két vagy több racionális döntés is következhet belölük. Így az a helyzet is előállhat, hogy az állampolgár által a jogszabálynak tulajdonított értelem különbözhet a helyes, a jogszabálynak a bíró által tulajdonított jogi értelemtől. Azt kell tehát rögzíteni, hogy „az értelmezés valószínűleg elkerülhetetlen, és bizonyára a bírói ítélkező tevékenység alapvető részét képezi a büntetőjogban... Az értelmezés során a bíró által tett választások politikai választások abban az értelemben, hogy az állampolgárok és a közösség életére lesznek hatással, valamint abban az értelemben, hogy a bírák a helyes értelmezés kiválasztásával ténylegesen jogot alkotnak." ${ }^{0}$ Ebből következően a lényegi kérdés az lesz, hogy miképpen ragadható meg a normavilágosság követelménye a bírói gyakorlatban.

Jómagam semmi körmönfontabbat nem értek a jog alatt, mint annak megjóslását, ténylegesen mit tesznek a bíróságok." [HoLmes, Oliver Wendell: A jog ösvénye. Jogelméleti Szemle, 2010/4. http://jesz.ajk.elte.hu/ oliver44.html (letöltés ideje: 2018. 10. 25.)] E tanulmány szerzője azonban nem ért egyet Holmesnak azzal a tézisével, hogy a jog természetét az idézetben említett rossz ember nézőpontjából kell tisztázni és vizsgálni.

29 HART, Herbert L. A.: A jog fogalma. Osiris, Budapest, 1995, 149.

30 Ashworth, Andrew: Interpreting Criminal Statutes. A Crisis of Legality? Law Quarterly Review, 1991/107, 446. 


\section{A határozottság problémája a bírói gyakorlatban}

A határozottság kérdése a bírói gyakorlatban - megítélésem szerint - nyelvi kérdésként jelenik meg, ami azt jelenti, hogy a büntetőjogban a jogszabályok értelmének feltárását a nyelvi értelmezés módszere uralja. A bírák indokolásaikban előszeretettel alkalmazzák az értelmező kéziszótárak meghatározásait, illetve gyakran a jogszabályokba foglalt fogalmak egyszerü, hétköznapi jelentésének meghatározására törekszenek. Úgy tünik, hogy a büntetőjogi esetekben a bírák tartózkodnak például a jogszabály teleologikus értelmezésétől vagy az ún. alkotmánykonform értelmezéstöl, amelyek célja, hogy a jogszabály mögöttes igazoló elveit feltárva vagy a jogeset által érintett alkotmányos értékek tartalmának vizsgálatával határozzák meg a jogszabály tartalmát. ${ }^{31} \mathrm{~A}$ büntető ítéletek megalapozásában tehát a jogszabályok szemantikai tartalmának feltárása játszik alapvető szerepet. Ezen értelmezési módszer alkalmazását természetesen nem a puszta szokás vagy ad hoc választás igazolja, hanem a tanulmány elején említett, a jogállamiságot megalapozó elvek állnak a hátterében: a jogbiztonság a büntetőjogban úgy érhető el, ha a bírák a jogszabályok szövegéből, egyszerű, hétköznapi jelentéséből következő döntéseket hoznak.

A jogelméletben Blutman László képviseli azt a nézetet, hogy a bírói érvelést a jogszabályok nyelvi értelmezésének kell megalapoznia. Álláspontjából azt a következtetést lehet levonni, hogy a jogi érvelés és a jogi gyakorlat nem pusztán a jogászok ,játszótere”, amelyből az állampolgárok ki vannak zárva. Mivel a jog az állampolgárokat kötelezi, elengedhetetlen számukra, hogy a jogi szabályokat és állításokat egyszerű, számukra is érthető formában közöljük. Blutman állítása szerint - annak ellenére, hogy a nyelvi értelmezés nem a legideálisabb módszer a jogszabályok jelentésének feltárására - a bíráknak a jogszabályok hétköznapi értelmére kell alapozniuk az ítéleteket. E követelmény mögött a hatalommegosztás elve, a jogbiztonság elve, a koherens és konzisztens bírói gyakorlat kialakításának elvárása húzódik meg. A nyelvi értelmezés elönye a többivel szemben - Blutman szerint abban áll, hogy viszonylag objektív alapot képes biztosítani ahhoz a törekvéshez, hogy a jogi állításokat, bírói döntéseket érthetővé, világossá tegyük a címzettek számára, hiszen a fogalmak hétköznapi jelentésének feltárásával olyan értelmet tulajdonítunk a jogszabálynak, ahogy azt a józan gondolkodású laikus átlagpolgár is értelmezné. A nyelvi értelmezés következetes alkalmazása hozzájárulhat egy koherens és konzisztens, kiszámíthatóbb bírói gyakorlat kialakításához, miközben arra is képes, hogy - azáltal, hogy kizárja a jogeseteket érintő erkölcsi, igazságossági értékek mérlegelését - minimálisra szorítsa a bírák önkényes megfontolásainak hatását a döntésre. Tehát a hatalommegosztás elvének és a jogbiztonság érvényesülésének biztosítéka a nyelvi értelmezés alkalmazása. ${ }^{32}$

Ezzel szemben az az álláspontom, hogy a jogbiztonság érvényesülése a jogban és az ítélkezésben nem lehet pusztán nyelvi vagy nyelvelméleti kérdés, illetve a hétköznapi vagy egyszerủ jelentés kutatásának problémája az ítélkezésben. Az a kérdés,

\footnotetext{
31 BENCZE Mátyás: Elvek és gyakorlatok. Jogalkalmazási minták és problémák a birói ítélkezésben. Gondolat, Budapest, 2011, 169-171.

32 Blutman László: Bírói jogalkalmazás és szöveghű értelmezés. Jogesetek Magyarázata, 2010/4, 94-104.
} 
hogy a jog határozott-e, avagy sem, nem pusztán nyelvi probléma. Ezzel kapcsolatban Dworkin állításával értek egyet: „...a jog más társadalmi jelenségektől eltérően argumentatív gyakorlat. A gyakorlat minden egyes résztvevője megérti, hogy az a kérdés, hogy mit követel vagy tilt meg a jog, bizonyos jogi állitások igazságától függ, amely állitásoknak értelmet kizárólag a jogi gyakorlat által és azon belül tulajdoníthatunk. A gyakorlat legnagyobb részt abból áll, hogy a jogi állítások tartalmát kifejtjük és érvelünk az igazságuk megalapozása érdekében."33

Szintén Ronald Dworkin hívta fel a figyelmet arra, hogy a jogászok, bírák gyakran nem értenek egyet abban a kérdésben, hogy a jog mit követel meg. Ez a véleményeltérés azonban nem pusztán nyelvi természetű. A jogszabályokba foglalt fogalmak nyelvi szempontú vizsgálatával nem lehetséges a jogászok között fennálló racionális egyet nem értést minden esetben eloszlatni. A helyes jogi döntéssel kapcsolatos véleményeltérés a jogászok között a nyelvi „bonyodalmaknál”, a hétköznapi vagy egyszerủ jelentésre vonatkozó vitáknál komplexebb problémát jelöl. Dworkin arra utal, hogy amikor a bírák, illetve általában a jogászok nem értenek egyet ugyanazon jogeset helyes jogi megoldását illetően, akkor valójában abban nem értenek egyet, hogy melyek a jog forrásai, amelyek relevánsak lehetnek döntést alátámasztó indokként. Ha két bíró például nem ért egyet egy eset helyes jogi megoldásában, akkor az a helyzet állhat fenn, hogy két különböző elvi felfogást védelmeznek abban a kérdésben, hogy mi a jog, milyen indokok tekinthetők a jog forrásainak. Azaz elméleti véleményeltérés áll fenn közöttük a jog természetével kapcsolatban és abban, hogy milyennek kellene lennie a jognak. ${ }^{34}$

A nyelvi jelentéssel kapcsolatos érvek nem nyújtanak minden esetben segítséget a helyes jogi döntés kialakításában. A nyelvi értelmezés esetleg még zavarosabbá teheti az érvelést. Ezt tapasztaljuk például az ún. „graffitiesetben”, amikor mind az ügyész, mind pedig a bíró a nyelvi értelmezés által feltárt érvekkel támasztotta alá álláspontját, mégis különböző álláspontra jutottak. Az ebben a határozatban kifejtett indokolás megvilágítja, miért problematikus az értelmező kéziszótárakhoz vagy pusztán nyelvi érvekhez folyamodni. ${ }^{35}$ Ebben az esetben a vádlottat falfirka elhelyezésével elkövetett rongálás miatt helyezte vád alá az ügyész. A vádlott festékszóróval egy magántulajdonban álló ponyvára helyezett el egy rövid szöveget, egy jogszerü demonstráció közben így fejezte ki véleményét. A jogi kérdés az volt, hogy az említett cselekmény falfirkával elhelyezett rongálásnak minősül-e. A bíró felmentette a vádlottat, azzal érvelt, hogy a vádlott nem követte el a rongálást, mert a cselekmény nem tartozik a graffiti jelentéstartományába, hiszen a falfirka hétköznapi vagy egyszerü jelentését tekintetbe véve elmondható, hogy azt kizárólag falra lehet elhelyezni. A fal elmozdíthatatlan, végleges építmény része, arról a firkát állagsérelem nélkül nem lehet eltávolítani. Az ügyész ezzel szemben a falfirka törvényi fogalmát vette figyelembe, amely így hangzik: Btk. 371. § (7) E § alkalmazásában falfirka: festékszóróval, filctollal vagy bármilyen más felületképző anyaggal létrehozott képi, grafikus vagy szöveges felületbevonat, amely nem a vagyontárgy rendeltetésszerü

33 Dworkin: Law's Empire. The Belknap Press of Harvard University Press, Cambridge, Massachusets, $1986,5$.

34 Dworkin: i. m., 6-8.

35 Lásd az EBD 2016. B. 5. számú határozatot. 
használatához szükséges. Az ügyész szerint - mivel a törvényi fogalom „vagyontárgyat" említ, az pedig hétköznapi nyelvi értelme alapján lehet bármilyen vagyontárgy, annak jelentése kiterjed a magántulajdonban lévő, elmozdítható ponyvára is. A két álláspont között „igazságot tenni” nyelvi érvekkel nem lehet, a szövegen túli érvek mérlegelésére lett volna szükség (például a véleménynyilvánítás szabadságának tekintetbe vételével). Tehát „...a szótár leginkább arra alkalmas, hogy bizonyítsa, egy szónak egynél több jelentése is lehet, arra egyáltalán nem alkalmas, hogy egy bizonyos kontextusban rámutasson az egyetlen helyes jelentéstartalomra" . ${ }^{36}$

Problémaként merülhet fel azokban az esetekben is, amelyekben a jogszabály szövege világos és egyértelmú még a laikus polgár számára is, azonban a szövegből következő döntés esetleg igazságtalannak, méltánytalannak tűnik. Az ilyen esetek segítségével is megvilágíthatjuk, hogy a jogszabályok határozottságának tisztázása nem pusztán nyelvi kérdés. A nyelvi jelentéssel kapcsolatos megfontolások a büntetőjogban rendkívül fontosak, azonban e megfontolások a jogi problémáknak csak a felszínét érintik. „Az értelmezés nem lehet pusztán az értelmező kéziszótárak olvasgatásának ügye, hanem azt olyan tevékenységként kell felfogni, amely során a szavaknak jelentést azok releváns törvényi kontextusában és dogmatikai összefüggéseinek ismeretében tulajdonítunk." 37

Meglátásom szerint a büntetőjogban is elkerülhetetlenek az olyan esetek, amelyek megítélése során a bírónak a jogszabály szövegén túli indokok mérlegelését kell elvégeznie. Mivel azonban ezekre a jog szövegén túli indokokra továbbra sem lehet korlátlan módon hivatkozni, szükség van egy elméletre arról is, hogy mik lehetnek ezek az indokok, és mikor folyamodhat azokhoz a bíró az esetek eldöntése során. Ebben a dolgozatban nincs arra mód, hogy ezt az elméletet kifejtsem, pusztán utalnék arra, hogy a jogszabályok szövegén túli indokok forrása természetesen nem lehet a bírák intuíciója, szubjektív erkölcsi véleménye vagy érzelmei. ${ }^{38}$ Ezekben az esetekben fel kell ismerniük, hogy nem spórolható meg a büntetőjogot vagy a jogot általában megalapozó erkölcsi és politikai elvek és dogmatikai összefüggések tartalmának tisztázása, a büntető jogeset által érintett alapvető jog vagy alkotmányos érték tartalmának kifejtése. Ezek az értékek a közösségek politikai moralitásának

36 Ashworth: i. m., 428.

37 Ashworth: i. m., 446.

38 Azzal az állásponttal sem értek egyet, hogy a jog bizonytalanságait a társadalom közös erkölcsi nézeteire hivatkozva kellene eloszlatni. Jakab András egy tanulmányában amellett érvel, hogy a bíráknak a társadalom közös erkölcsi nézeteit kell figyelembe venni az ítélkezés során. Jakab állítása szerint annak érdekében, hogy a bíró tudatában legyen a közös erkölcsi nézeteknek, nem kell mást tennie, mint újságot olvasnia és bíróságon kívüli emberekkel beszélgetnie, elég józan paraszti ésszel és minimális erkölcsi érzékkel rendelkeznie. (JAKAB András: Ki a jó jogász, avagy tényleg jó bíró volt-e Magnaud? Jogesetek Magyarázata, 2010/1, 87.) Ez a felfogás az ítélkezésnek általánosságban is helytelen stratégiáját támogatja, nem csak a büntető jogesetekben. A közös erkölcs nem lehet bírói döntések alapja. Egyrészt vitatott, hogy mit értünk „közös erkölcs” alatt, de még ha világos is lenne, mi az, a közös erkölcsi nézetek változnak, ráadásul egyáltalán nem jelent garanciát, hogy racionálisan átgondolt nézeteket jelenítenek meg. (Erről lásd H. L. A. Hart értekezését a pozitív és kritikai erkölcs megkülönböztetéséről. HART, Herbert L. A.: Jog, szabadság, erkölcs. Osiris, Budapest, 1999, 29-33.) Alkotmányos demokráciákban a bírák feladata, hogy a jog alapján ítélkezzenek. Ha „jó bírónak lenni” azt jelentené, hogy elegendő újságot olvasni és laikus polgárokkal beszélgetni, nem lenne értelme jogszabályokat létrehozni és a jogrendszert működtetni. 
részét képezik, olyan elvekről van szó, amelyeket a politikai közösség minden racionálisan gondolkodó tagja elfogadhat. Ha ilyen esetekben pusztán a szavak nyelvi értelmének feltárásán dolgozik, nem találja meg a helyes jogi megoldást.

A normavilágosság problémáját így elsősorban nem nyelvi kérdésként képzelem el. A legjobb kifejezés, amellyel meglátásom szerint megragadható a jog határozottságának problémája a bírói gyakorlaton belül, az ún. „magyarázaton alapuló határozottság" (explanatory clarity). ${ }^{39} \mathrm{Ez}$ azt jelenti, hogy a jog határozottságának kérdése azon (is) múlik, hogy a bíráknak az ítéleteikben világossá kell tenniük az érvelési láncolat minden egyes elemét. Ha elismerjük, hogy a bíró majdnem minden esetben választásra szorul, tehát a döntése nem következik kényszerítő erővel a jogszabály szövegéből, akkor elvárható, hogy a „választásait” és annak indokait tegye teljességében láthatóvá és világossá a döntés címzettjei számára. Ez magában foglalja azt a követelményt is, hogy a bíró tegye mérlegre a jogszabálynak a terhelt vagy védője által kifejtett értelmezését is, majd világosan magyarázza el, hogy a terhelt által a jogszabálynak tulajdonított jelentés miért nem lehet a helyes jogi döntés alapja. A jogszabály tartalmának világossága azon múlik, hogy a bíró milyen mértékben tette követhetővé azt az érvelési és következtetési láncolatot, amelyen keresztül eljutott a döntésig. (A jogszabály határozatlansága annál nyilvánvalóbb, minél nehezebb ezt az érvelési láncolatot felépíteni.) „A büntetőjognak alkalmasnak kell lennie arra, hogy a bírák az ítéleteiken keresztül elmagyarázhassák a tartalmát laikus polgárok számára, amelynek következtében világossá válik számukra, hogy miképpen alkalmazható az adott jogszabály a konkrét tényekre vonatkozóan."40

A „magyarázatra épülő határozottság” megnyilvánulásaként értékelhető például a Debreceni Ítélőtábla egyik ítélete, ${ }^{41}$ amelyben világosan nyomon követhető a bíró által hozott döntést megalapozó érvek egymásból következő láncolata, a döntés igazolása megmutatja, hogy a normavilágosság milyen formában ragadható meg a bírói gyakorlatban.

39 Ezt a fogalmat Jeremy Hordertöl kölcsönöztem. Lásd HoRder, Jeremy: Criminal Law and Legal Positivism. Legal Theory, 2002/8, 236.

40 Horder (2002): i. m., 236.

41 Az Ítélőtábla által elbírálandó eset kártalanítással kapcsolatos problémát ölelt fel, azonban hátterében egy büntetőügyben született határozat állt. A büntetőügy vádlottját ideiglenes kényszergyógykezelés alá helyezte a bíróság, és felmentette a vádak alól, mert az elkövetés idején elmebetegségben szenvedett. Az elkövetés idején hatályban lévő büntetőeljárási szabály szerint kártalanítás jár az ideiglenes kényszergyógykezelésért többek között, ha a bíróság a terheltet felmentette. Nincs helye kártalanításnak, ha a terheltet a bíróság felmentette és ezzel egyidejűleg elrendelte a kényszergyógykezelését. Ebben az esetben az ideiglenes kényszergyógykezelés eredményes volt, ezért a felmentéssel egy időben nem rendelte el a bíróság a kényszergyógykezelését. A felperes, a büntetőügy vádlottja kártalanítás iránt nyújtott be keresetet az ideiglenes kényszergyógykezelés elrendelése miatt, és a büntetőeljárási törvény alkalmazandó szakaszának nyelvi értelmezésére támaszkodott: mivel a bíróság felmentette, de nem rendelte el a kényszergyógykezelését, szerinte a jog alapján kártalanítás illeti. Nyelvi szempontból az eset minden eleme „kimerítette” a törvényi tényállási elemeket, azonban tekintetbe véve a kártalanítás célját, a mögötte meghúzódó igazolási elveket, a bíróság úgy ítélte meg, hogy a jog szerint nem jár a kártalanítás. Álláspontja alátámasztása érdekében a döntéshez vezető indokok és érvek teljes készletét megvilágította, amely során a jogszabályok értelmezésének módszereiről és azok tartalmáról is „felvilágosítást” adott a felperesnek. Lásd a Debreceni İtélőtábla Pf.I.20.574/2011/5. számú határozatát. 
Az eddigi példákból kiindulva felmerül a kérdés, hogyan állapíthatja meg az Alkotmánybíróság, hogy egy bizonyos büntetőjogi norma megfelel-e a normavilágosság követelményeinek? A testület egyik döntésében egy elméletileg megalapozottabb érvelésben fejtette ki, hogy a hivatalos személlyel szembeni engedetlenség tényállása a szabálysértésekről szóló törvényben alkotmányellenes, mert nem felel meg a normavilágosság követelményeinek. A jogszabály akkor hatályos szövege így szólt: 216. § (1) Aki a rendvédelmi szerv vagy a vámszerv hivatásos állományú tagja jogszerü intézkedésének nem engedelmeskedik, szabálysértést követ el. A Lévay Miklós által kifejtett érvelésben az alkotmányellenesség megállapításának, azaz a normavilágosság elve megsértésének alapja, hogy a kérdéses jogszabály által védett értékeket, a jogszabály mögöttes céljait, igazolási elveit tárjuk fel. Ezeket az értékeket és elveket tekintetbe véve megállapítható, hogy a jogalkotó túlságosan absztrakt módon fogalmazta-e meg a jogszabályt és túlságosan széles teret engedett-e a bíráknak a szabad mérlegelésre. Ebben az esetben a testület szerint a vizsgált jogszabály mögött meghúzódó igazolás a közigazgatás, rendészeti igazgatás rendjének biztosítása, az intézkedések zavartalan végrehajtásához füződő érdek, tágabb értelemben pedig a közrend és közbiztonság fenntartása. $E$ célok tekintetbe vételével az „engedetlenség” fogalma túl absztrakt, mert olyan magatartások szankcionálását is lehetővé teszi, amelyek hétköznapi értelemben „engedetlenségnek” számíthatnak, de nem irányulnak az intézkedések zavartalan végrehajtása ellen, így nem is jelentenek veszélyt a közbiztonságra (például az intézkedő személy szóbeli minősítése vagy azzal kapcsolatos vélemény kifejezése). Emiatt fennáll a veszélye, hogy önkényes bírói döntések, inkoherens bírói gyakorlat alakul ki a jogszabály értelmezése mögött. A testület ezért felhívta az Országgyűlés figyelmét arra, hogy pontosan fogalmazza meg az elkövetési magatartást ebben a tényállásban. ${ }^{42}$

\section{Milyen elméleti keretben ragadható meg a normavilágosság problémája a bírói és az alkotmánybírósági gyakorlatban?}

A fentiek alapján alapvető tézise ennek a dolgozatnak, hogy a normavilágosság problémája nem pusztán nyelvi kérdés. Úgy gondolom, hogy a normák pontos meghatározottságára épülő jogbiztonság elvének a büntetőjogban köze van azokhoz az erkölcsi, politikai értékekhez, amelyek védelmére a büntetőjog hivatott, illetve amelyek a büntetőjog erkölcsi igazolását nyújtják. Röviden: a büntetőjog természetével kapcsolatos elmélethez. A büntetőjogot megalapozó elmélet teljes kifejtésére szintén nincs lehetőség e tanulmány keretében, azonban néhány alapvető megfontolás vázlatára igen. A büntetőjogot megalapozó elméletek rövid ismertetéséhez R. A. Duff megfontolásait használom. Duff a büntetőjognak kétféle lehetséges elméleti megalapozását vázolja. Mindkét elméletnek vannak implikációi arra a kérdésre vonatkozóan, hogy a határozottság problémáját miképpen lehet megragadni a büntetőjogban.

42 Lásd az Alkotmánybíróság 31/2015. (XI. 18.) számú határozatát. 
A büntetőjog természetét megalapozhatjuk egyrészt a jogpozitivista elmélet keretei között. Ezen belül védelmezhetjük azt a tézist, hogy a büntetőjog szabályai autoritatív indokok abban az értelemben, hogy tartalomfüggetlen, kizáró indokokat szolgáltatnak a cselekvések meghatározására. Ez azt jelenti, hogy egyfajta parancsként, a büntetőjog által szolgáltatott cselekvési indokok önmagukban, a címzettekre vonatkozó egyéb körülmények mérlegre tételének lehetőségét kizárva határozzák meg a magatartást. ${ }^{43} \mathrm{~A}$ büntetőjogi normák olyan parancshoz hasonló szabályok, amelyek engedelmességi kötelezettséget teremtenek tartalmukra tekintet nélkül. Ebben az elméleti keretben az engedelmességi kötelezettség forrása kizárólag az, hogy az adott cselekményt a jog szabályozza, a büntetőjog nem kívánja meg, hogy az állampolgárok egyetértsenek a szabályok tartalmával. Mivel a büntetőjogi normák elsődlegesen az állampolgárok számára megfogalmazott autoritatív indokok, az az elvárás fogalmazódik meg a jogalkotóval szemben, hogy a normákat világos, egyértelmü, az átlagpolgár számára is követhetö, érthető formában hozza létre.

A büntetöjog pozitivista felfogásában - miután a törvényhozó megalkotta és kihirdette a jogszabályt - nem lehet annak érvényességét a tartalma alapján vitatni. Elvileg nem tehető fel az a kérdés, hogy milyen erkölcsi igazolás áll a törvény hátterében, hogy milyen erkölcsi alapon rendelte büntetni a jogalkotó a törvényben szereplő magatartást. A jogi érvelés terén ez úgy mutatkozik meg, hogy a jogszabályok értelmezése során nem lehet olyan értelmezési módszereket alkalmazni, amelyek a jogszabály szövegén túlmutató igazolási érvek mérlegre tételét teszi lehetővé. ${ }^{44}$ A büntetőjog ilyetén felfogása mögött felismerhető az az alapvető tézis, amely szerint a jog érvényessége nem függhet annak erkölcsi értékétől. Ez a megfontolás például Joseph Raz elméletében a társadalmi források tézisében és a jog közvetítő szerepének hangsúlyozásában tükröződik. ${ }^{45}$

A jogpozitivista elméletek számára ezért rendkívül fontos a jogbiztonság értéke, ezen belül a jogszabályok pontossága és érthetősége, amelynek biztosításában a jogalkotónak van nagy szerepe. A jogalkotó feladata, hogy a büntető normákat minél érthetőbb és világosabb formában kommunikálja a címzettek és a jogalkalmazók számára.

A büntetőjog természetével kapcsolatos másik jogelméleti felfogást nevezhetnénk „dworkiniánus” felfogásnak. Habár Ronald Dworkin elvileg a büntetőjog pozitivista felfogását támogatta ${ }^{46}$ ebben a dolgozatban a büntetőjog e másik, antipozitivista felfogását „dworkiniánusnak” nevezném, mert több olyan elemet is tartalmaz, amelyek véleményem szerint Dworkin elméletében is meghatározóak.

A „dworkiniánus” felfogás ${ }^{47}$ azt a megfontolást védelmezi, hogy minden politikai közösségben léteznek olyan magatartások, amelyeknek a helytelensége független

43 A tartalomfüggetlen, kizáró indokok természetével kapcsolatban lásd RAZ, Joseph: Practical Reason and Norms. Oxford University Press, Oxford, 1999, 35-45.

44 Duff, R. Anthony: Rule-Violations and Wrongdoings. In: Shute, Stephen-Simester, Andrew (eds.): Criminal Law Theory - Doctrines of the General Part. Oxford University Press, Oxford, 2002, 51-53.

45 HORDER (2002): i. m., 222.

46 HORDER (2002): i. m., 222.

$47 \mathrm{Az}$, hogy Dworkin valójában hogyan gondolkodna a büntetőjog karakteréről, egy külön tanulmányt igénylő kérdés, ebben a dolgozatban nem térek ki részletesen. 
attól, hogy a büntetőjogban tilalmazza-e valamely jogszabály vagy sem. A legjobban ezt az angolszász büntetőjogban kialakított, a büncselekmények kétféle kategóriájának tulajdonságaival illusztrálhatjuk. A bűncselekmények egyik típusát mala in $\mathrm{se}^{48}$ cselekményeknek nevezik. Ezek olyan magatartásokat jelölnek, amelyek természetüknél fogva „bűnösnek” tekinthetők, anélkül is elfogadhatatlannak tartjuk ezeket a magatartásokat, hogy a büntetőtörvényekben tilalmaznánk őket. (Például emberölés, szexuális erőszak, rablás stb.) A mala in se körbe tartozó bűncselekmények olyan magatartásokat jelölnek, amelyek közvetlenül sértik a politikai moralitás közösségben tiszteletben tartott értékeit, elveit. ${ }^{49} \mathrm{~A}$ mala prohibita jellegủ büncselekményekre nagy vonalakban az jellemző, hogy azok helytelenségét, elfogadhatatlanságát maga a jogszabályban rögzítés alapozza meg. Tehát önmagukban, a szabályozástól függetlenül, természetüknél fogva nem tekinthetők bủnösnek vagy helytelennek. ${ }^{50}$

Anélkül, hogy mélyebben elemezném a két kategória megkülönböztetésének lényegét, e dolgozat céljai szempontjából elég lesz most, ha csak a mala in se magatartások mögötti ráció rövid megvilágításával mutatok rá a „dworkiniánus” elmélet relevanciájára a büntetőjogban.

Ebben az elméleti megközelítésben a büntetőjog lényege nem az, hogy a címzettjeit „parancsok” formájában utasítsa a helyes magatartásra, hanem az, hogy azoknak az elveknek a tartalmát kommunikálja, amelyek a büntetőjog egészének igazolását adják. A büntetőjog természetének e felfogása az alkotmányos demokrácia, illetve a demokratikus közösség olyan értelmezésére építi fel téziseit, amelyben a tagok az egymással való bánásmód, illetve az állami hatalom alapjait kölcsönösen elfogadott és tiszteletben tartott erkölcsi és politikai elvek, értékek (politikai moralitás) mentén rendezik. A politikai moralitás elvei ugyanis arra a kérdésre is kiterjednek, hogy milyen magatartásokat indokolt büntetni egy politikai közösségben, mi lehet az erkölcsi alapja a büntetőjogi felelősségre vonásnak, milyen elvi korlátok határozzák meg a büntető hatalom alkalmazását stb.

Ebböl következően a büntetőjogi normáknak való engedelmesség alapja nem pusztán az, hogy bizonyos tilalmakat a jogalkotó törvénybe foglalt. Az engedelmesség alapja a törvények mögött meghúzódó erkölcsi igazolás: az a kérdés, hogy egy adott magatartást milyen indokokkal, azaz milyen erkölcsi igazolás mellett rendelt büntetni a törvényhozó, a büntetőjog fogalmának része, attól nem választható el. Ezért a jogalkotás és a jogalkalmazás során is szerepet kell kapniuk ezeknek az elveknek a büntetőjogi normák és a bírói döntések megalapozása során. A jogalkotás során ez Duff szerint oly módon érvényesülhet, hogy a törvényhozók a büntetőjogi szabályokat ún. „„ömör fogalmak” (thick concepts) segítségével fejezik ki. Az ilyen jellegủ fogalmak absztrakt fogalmak, azonban tartalmukban azokat az elveket és értékeket jelenítik meg, amelyek a büntetőjog mögött meghúzódnak. A címzettek

48 Ebben a dolgozatban szintén nem fejtem ki bővebben a mala in se és mala prohibita jellegű bűncselekmények közötti különbség lényegét. Az angolszász büntetőjogban alakult ki e megkülönböztetés hagyománya, a magyar büntetőjogban nem jellemző e két büncselekménytípus közötti különbségtétel. Ennek ellenére az kérdéses elméleti probléma megvilágítására alkalmas a magyar büntetőjogban is.

49 Duff: i. m., 53.

50 Duff: i. m., 54. 
azért lesznek képesek egyértelmủen meghatározni e fogalmak alapján, hogy mit kell tenni, mert azok tartalma a politikai moralitás elveinek jogi kifejeződései. ${ }^{51} \mathrm{E}$ fogalmak helyes alkalmazása azon múlik, hogy az állampolgárok és a bírók „felismerik és megértik a fogalmak mögött meghúzódó értékek tartalmát". ${ }^{52}$ Ezen elmélet alapján a büntetőjog nem más, mint olyan normatív nyelvezet, amely a közösség tagjai által elfogadott és tiszteletben tartott erkölcsi és politikai értékeket közvetíti a címzettek számára. „...a büntetőjog különös része számos büncselekményt definiál. Ennek során a jogtalan magatartások (public wrongs) olyan készletét határozza meg, amelyeket formálisan és nyilvánosan elítélendőnek tartunk. Bár a különös részi tényállásokat gyakran tilalmak formájában állapítják meg [...], ez félrevezető, hiszen azt sugallja, hogy a jog nem más, mint parancsok és utasítások foglalata, amelyeknek az állampolgárok engedelmességgel tartoznak, bizonyos magatartások megtiltásával pedig az állam igényt tart arra a hatalomra, hogy olyan magatartásokat is büncselekménynek nyilvánítson, amelyek elözetesen nem számítottak bünös magatartásnak. A büntetőjog azonban nem tart igényt ilyesfajta hatalomra vagy autoritásra. Az autoritásigénye inkább arra vonatkozik, hogy a töle függetlenül is elfogadhatatlannak minősülő magatartásokat (olyan cselekményeket, amelyek a büntetőjogtól függetlenül is léteznek és természetüknél fogva bünösnek számítanak) törvényben jogszerütlennek minősítsen. Ennek következtében e tényállások formálisan is az egész közösségre vonatkozó előirásokat tartalmaznak, és amennyiben az szükséges, autoritatív büntetőjogi szabályban nyernek meghatározást." 53

Mindezekböl adódik, hogy magam egy rugalmasabb büntetőjogi nyelvezet és rugalmasabb büntetőjogi érvelés mellett foglalok állást, miközben távol áll tőlem, hogy elimináljam a normavilágosság és jogbiztonság követelményeit a büntetőjogból. A normavilágosságnak és a jogbiztonságnak inkább egy komplexebb felfogását védelmezném, amely túlmutat e követelmények nyelvi szempontú elemzésén, és álláspontom szerint a bírákra „hárul a feladat”, hogy a jogbiztonságnak ezt a komplexebb felfogását beépítsék a jogalkalmazói gyakorlatba. Meglátásom szerint azonban egyelőre a jogbiztonság nyelvi szempontú megközelítése uralja a jogászi érvelést, amely akár még abban az esetben is hangsúlyos lehet, ha a jogi szövegböl következő döntés nem lenne észszerü. ${ }^{54}$

51 DuFF: i. m., 56-61.

52 DufF: i. m., 61.

53 Duff, R. Anthony: A Criminal Law We Can Call Our Own? Northwestern University Law Review, 2017/6, 1496.

54 Lásd például az ügyészi érvelés leírását Deák Zoltán cikkében. A Szegedi İtélőtábla egyik döntésében a bíróság a teleologikus értelmezés segítségével a jogszabály értelmét annak mögöttes céljaira, igazolási elveire tekintettel határozta meg, és felmentette a vádlottat, aki amiatt, hogy elmaradjon a büntető tárgyalása, felhívta a bíróságot és azzal fenyegette, hogy felrobbantja az épületet, ha nem engedik ki a fiát a börtönből. A vádlottnak nem volt börtönben ülő fia, sem pedig eszköze és megfelelő tudása a cselekmény végrehajtásához. Az ügyész viszont terrorcselekménnyel fenyegetés miatt helyezte vád alá, mert ez a cselekmény formálisan - az elbírálás idején hatályban lévő 1978. évi IV. törvény szerint - kimerítette ennek a tényállásnak az elemeit. Az ügyész a jogbiztonságra hivatkozva a terrorcselekménnyel fenyegetés nyelvi értelmezését támogatta, miközben - véleményem szerint - a nyelvi értelmezéssel megalapozott döntés észszerűtlen, ha tekintetbe vesszük a jogszabály (terrorcselekménnyel fenyegetés) által védett értékeket és célokat. Lásd 
Meglátásom szerint a jogbiztonság, ezen belül is a normavilágosság kérdése összetettebb probléma a jogi fogalmak és szövegek nyelvi értelmezésénél, komplexebb kérdéskört ölel fel a szemantikai elméleteknél. A büntetőjog rendkívül fontos erkölcsi és politikai értékek, elvek kifejeződése, amelyekre való hivatkozást, amelyek mérlegre tételét nem lehet „megspórolni” azokban az esetekben, amikor a jogi szöveg nyelvi jelentése bizonytalan, de sokszor azokban az esetekben sem, amikor a nyelvi jelentés egyértelmü.

Ideje visszatérni ahhoz az esethez, amelyet a tanulmány elején tárgyaltam. Annak ellenére, hogy a garázdaság vétségének tényállása valóban absztrakt és általános megfogalmazású, nem kérdőjelezném meg az alkotmányosságát. Véleményem szerint léteznek olyan esetek, amelyek egyértelműen kimerítik e tényállás fogalmi elemeit, amelyek megítélésénél lehet aggályos a garázdaság megállapítása. A tényállás puszta nyelvi elemzése azonban nem jelent megoldást olyan esetekben, amelyeknél kétségek merülnek fel.

Meglátásom szerint a fent említett, a Sándor-palota előtti demonstráció során megvalósított cselekményről nem állapítható meg automatikusan, hogy garázdaság történt. A bíróság ugyanis nem vette tekintetbe azokat a körülményeket, amelyek relevánsak lettek volna az eset helyes megítélése szempontjából. Például azt, hogy a magatartást egy jogszerű demonstráció keretei között valósították meg, az elkövetők szándéka nem terjedt ki arra, hogy helyrehozhatatlan kárt okozzanak, a cselekményüket a véleményük kinyilvánítása miatt követték el. A véleménynyilvánítás szabadsága tartalmának vizsgálata és annak határai ebböl a szempontból a bírói indokolás fontos eleme kellett, hogy legyen, de az indokolás nem tartalmazta ezt a mérlegelést. ${ }^{55}$

A problémát talán azzal is megvilágíthatjuk, ha ezt az esetet összehasonlítjuk egy másik esettel, amely szintén a garázdaság tényállását érinti. Az EBH 1999./2. számú bírói döntésben a történeti tényállás szerint a vádlott egy úrnapi körmenetben részt vevő tömegbe hajtott autójával, és trágár szavakat kiabálva próbálta útjából félretolni az embereket, majd egy riasztópisztollyal fenyegette a körmenet résztvevőit. A bíróság szerint a vádlott cselekménye kimerítette a lelkiismereti és vallásszabadság megsértése tényállást.

A korábban hatályban lévő Büntető Törvénykönyv szerint így hangzott a tényállás: 174/A. § Aki mást a) a lelkiismereti szabadságában erőszakkal vagy fenyegetéssel korlátoz, b) a vallásának szabad gyakorlásában erőszakkal vagy fenyegetéssel akadályoz, büntettet követ el, és három évig terjedő szabadságvesztéssel büntetendő.

Nem értek egyet a bírói döntéssel. Ha a tényállás nyelvi értelmezéséből indulunk ki, az eset formálisan kimerítette a fogalmi elemeket, hiszen a vádlott viselkedésével akadályozta, hogy az úrnapi körmenet résztvevői nyugodt körülmények között hajtsák végre a szertartást. Ha e jogszabály nyelvi értelmezésén túllépünk, és megvizsgáljuk a mögötte rejlö igazolási elveket, megállapíthatjuk, hogy az eset valójában nem a vallásszabadság megsértésének minősül. A vallásszabadság megsértése

DEÁK Zoltán: A Szegedi Ítélőtábla döntése a terrorcselekménnyel fenyegetés és a közveszéllyel fenyegetés elhatárolásáról. A fenyegetés fogalmának értelmezése. Jogesetek Magyarázata, 2014/2, 46-57.

55 Bócz: i. m., 6, Budai Központi Kerületi Bíróság 10. B. I.650/2017/3. számú ítélete. 
tényállás mögött meghúzódó védendő érték természetesen a vallás gyakorlásának szabadsága mint alapjog. Ebböl következően - véleményem szerint - az elkövetőnek kifejezetten arra tekintettel kell a sértetteket akadályozni a vallás gyakorlásában, hogy ők valamely vallás követői. Mivel ebben az esetben az elkövető tette mögött nem ez a szándék húzódott meg, nem állapítható meg a vallásszabadság megsértése, hanem a garázdaság vétsége. ${ }^{56} \mathrm{~A}$ jogszabályok mögött meghúzódó értékek racionális vizsgálata nemhogy hátrányt, hanem előnyt jelenthet a büntető ítélkezésben is, ha a helyes jogi döntés kialakítása a cél.

\section{Zárógondolatok}

Ebben a tanulmányban a jogbiztonságnak azon aspektusát elemeztem a büntetőjogban, amely a normavilágosság, a jog határozottságának kérdését érinti. Ennek az elvnek a követelményeit az Alkotmánybíróság gyakran elemzi, hiszen ezen elvre alapozva jogszabályok megsemmisítéséröl is dönthet. Álláspontom szerint az AB ritkán semmisít meg büntető jogszabályt a pontatlanságára vagy határozatlanságára hivatkozva. A legtöbb esetben a testület érvelésének lényege, hogy bizonyos büncselekményeket megszámlálhatatlanul sokféle módon lehet elkövetni, ezért a büntetőjogi szabályokat indokolt lehet absztrakt, általános formában megfogalmazni, hogy a büntetőjog képes legyen alkalmazkodni az új, elöre nem látott esetek megitélésére. Így véleményem szerint az AB elfogadja azt a nézetet, hogy az absztrakt, általános fogalmak tartalmának tisztázása a bírák feladata, akik értelmezés segítségével kialakíthatnak egy koherens és konzisztens bírói gyakorlatot: „[a] büntetöjogi kodifikáció sajátja, hogy a törvényi tényállások nemcsak a puszta felismerést kivánó leíró jellegü elemeket, hanem bírói mérlegelést követelő normatív elemeket is tartalmaznak.” „Az Alkotmánybíróság megítélése szerint a támadott jogszabályi rendelkezés megfogalmazás-módja nem gátja annak, hogy a törvényhozó által részletesen meg nem határozott fogalmakat a jogalkalmazó szervek - a védett jogi tárgyra is figyelemmel - tartalommal töltsék ki, illetve értelmezzék." 57

Természetesen alaposabb elemzés szükséges az állitásom megalapozásához, de feltételezésem szerint a bírói gyakorlatban a jogszabályok határozatlanságának problémája nyelvi problémaként jelenik meg, és a bírák kevésbé hajlamosak a jogszabályok mögött meghúzódó erkölcsi elvek feltárására és azok tartalmának tisztázására. A határozatlanság problémája leginkább akkor kezelhető, ha a büntetőjog természetét egyfajta „dworkiniánus” elmélet keretei között képzeljük el, amely lényege nagy vonalakban az, hogy a büntetőjog alapvető erkölcsi és politikai értékek, egy közösség politikai moralitásának közvetítöje, nem pusztán a jogalkotótól származó parancsok összessége. Ez a felfogás arra ösztönzi a bírákat, hogy rugalmasabb, nyitottabb érvelés segítségével igazolják döntéseiket, amelyben láthatóvá és érthetővé teszik az állampolgárok számára, hogy az alkalmazandó jogszabályok mögött milyen igazoló elvek és értékek húzódnak meg. Ezek a megfontolások nem jelente-

56 Lásd az EBH 1999./2. számú határozatot és BENCZE: i. m., 97-98.

57 3258/2015. (XII. 22.) AB határozat. 
nek szakítást a jogbiztonság elvével, inkább egy összetettebb, átfogóbb felfogását mutatják fel, amelyben a büntetőjog szövege nem semleges, zárt rendszer, hanem a közösség által elfogadott értékek közvetítője.

\section{Abstract}

The principles of legality in criminal law determine numerous requirements both for the legislator creating criminal statutes and for judges as well who decide criminal cases. One of the most important demands of legality is the principle of maximum certainty according to which the state must establish a system of criminal law in which the wording of the statutes are clear, precise and understandable for the citizens; and judges are able to interpret criminal rules without making arbitrary decisions. In the Hungarian legal system the demands of maximum certainty are represented by the principle of nullum crimen sine lege. This principle is called the "clarity of norms" doctrine in the practice of the Constitutional Court of Hungary (HCC) which is entitled to strike down criminal statutes which do not meet its requirements. The aim of this paper is to argue for the claim that the "clarity of norms doctrine" and the concept of certainty in criminal law is based mostly on considerations about the plain meaning of words and texts and lack a coherent theoretical background in the decisions of the HCC and in judicial practice as well. The author offers a more complex and coherent conception of certainty stating that its requirements relate not only to linguistic considerations but also to thinking over the moral and political values of criminal law as well. 